Ethiopian Journal of Environmental Studies \& Management 10(5): 588 - 596, 2017.

ISSN:1998-0507

doi: https://dx.doi.org/10.4314/ejesm.v10i5.3

Submitted: December 20, 2016

Accepted: June 06, 2017

\title{
GROUNDWATER QUALITY ASSESSMENT NEAR A NIGERIAN DUMPSITE
}

\author{
${ }^{*}$ MOKUOLU, 0.A., ${ }^{1}$ JACOB, S.0. ${ }^{2}$ AYANSHOLA, A.M. ${ }^{1}$ \\ ${ }^{1}$ Department of Water Resources and Environmental Engineering, Faculty of Engineering \\ and Technology, University of Ilorin, Ilorin, Kwara state, Nigeria \\ ${ }^{2}$ Department of Civil Engineering, Faculty of Engineering and Technology, University of \\ Ilorin, Ilorin, Kwara State, Nigeria
}

\begin{abstract}
Municipal solid waste collected in Nigeria are often disposed of in uncontrolled dumpsites and/or burnt in the open spaces and consequently causing significant pollution on surface water, ground water and the air. An investigational study was carried out on the level of pollution on groundwater near Gbagede dumpsite in Kwara state. Ground water samples, GW1, GW2, GW3 were taken at three different locations: $186 \mathrm{~m}, 290 \mathrm{~m}$, and $326 \mathrm{~m}$ from the edge of the dumpsite. Physicochemical parameters evaluated include; $\mathrm{pH}$, total hardness, Total Dissolved Solids, Total Suspended Solids, alkalinity, turbidity, Chemical Oxygen Demand, Biochemical Oxygen Demand, Dissolved Oxygen, Nitrate ion, Chloride ion, Sulphate ion, Electrical conductivity, Calcium ion and Magnesium ion using standard laboratory procedures. The results of the evaluations were compared with the World Health Organization (WHO) and Nigerian Standard for Drinking Water Quality (NSDWQ) to establish its suitability for human consumption. Results fell within the stipulated range of WHO and NSDWQ standard for drinking water. It was however observed that the water quality improves with distance from the dumpsite. Statistical analyses indicated mild differences among all the parameters tested for in the samples at 95\% confidence level. Uncontrolled accumulation of leachates from the dumpsite may pose potential risk to the source of water for the community in the near future. It was recommended that the dumpsite be relocated from the current residential area.
\end{abstract}

Key Words: Groundwater, Assessment, Contaminants, Solid-waste, Water quality

\section{Introduction}

Drinking water quality is affected by the presence of micro-organisms and soluble salts. Using water polluted by municipal solid waste for bathing, food irrigation can also expose individuals to disease organisms and other contaminants (Adekunle et al., 2007). An assessment commissioned by the United
Nations, reported that " 4,000 children die each day as a result of diseases caused by ingestion of filthy water and most of them are in Africa". (Lo-Karija et al., 2013; Raman and Narayanan, 2008).

A large percentage of population people in developing nations do not have access to improved drinking water both in rural and urban area. This situation

*Corresponding Author: Mokuolu, O.A.

Email: olubunmimokuolu@yahoo.com 
becomes more critical in urban areas and it can be linked to rapid urbanization which has led to increase in urban population and greater demand for water supply and sanitation services in the country. Access to drinking water has thus become a vital and persistent environmental health challenge in developing countries and all over the globe (Cosgrove and Rijsberman, 2000; Ruiz-Mier and Ginneken, 2006; Okonkwo, 2010). For most communities, the most secure source of safe drinking water is pipe-borne water from municipal water treatment plants. But this source has been found to be insufficient to satisfy demands. Apart from its insufficiency of supply, the water distributions in urban areas are not extended to suburb communities like Gbagede, the study area. Hence, hand dug wells (a category of groundwater) among their sources has been found to be readily explored to meet community water requirement or make up the short fall from municipal water supply where such exists (Musa and Fumen, 2013; Ayanshola, 2013).

Groundwater quality is threatened mainly by human activities, although harmful substances are sometimes introduced by natural processes (Zaporozec, 1981). Sustainable groundwater management must be based not only on prevention of the overexploitation of groundwater resources but also on prevention of contamination, because unlike treatment at the point of use, prevention protects all of the resource (Romijn, 2002). Ground water and contaminants can move rapidly through fractures in rocks. Fractured rock presents a unique problem in locating and controlling contaminants because the fractures are generally randomly spaced and do not follow the contours of the land surface or the hydraulic gradient. Contaminants can also move into the ground water system through macropores root systems, animal burrows, abandoned wells, and other systems of holes and cracks that supply pathways for contaminants (Romijn, 2002). Research on groundwater assessment showed that the contamination of the groundwater was more dependent on proximity to dump sites (David and Oluyege, 2014; Akinbile and Yusoff, 2011; Adekunle et al., 2007). Hence, there is a need to so study the effect of solid waste dump site on the groundwater quality in the study area.

Solid waste has been a result of man's activities from his earliest civilization, made more prominent during the industrial revolution, intensified by technological development of twentieth century and given political and economic exposure by the passage of solid waste act of 1965. In Nigeria, management of solid waste became a phenomenon in the early 1970s, when the oil boom compounded the rapid industrialization and the urbanization problems, urbanization provides a lot of opportunities and benefits but it also results in some negative impacts (Burmamu et al., 2014). These negative impacts include declining quality of health of people due to the poor sanitary conditions, pressure on social amenities, and scarcity of land for constructing sanitation facilities. According to United Nation Development Programme survey report, solid waste disposal is the second most pressing problem facing urban city dwellers after unemployment. It constitutes a major source of 
environmental hazard which accounts for an estimated $25 \%$ of the total burden of diseases worldwide (Kwabena and Worlanyo, 2015). The mountainous heaps of solid wastes that deface Nigerian cities and the continuous discharges of industrial contaminants into streams and rivers without treatment motivated the federal government of Nigeria to promulgate Decree 58 for the establishment of a Federal Environmental Protection Agency (FEPA) on 30 December 1988. A national policy on the environment was formed and the goals of the policy include: to secure for all Nigerians a quality of environment adequate for their health and well-being; to raise public awareness and promote understanding of the essential linkages between the environment and development; and to encourage individual and community participation in environmental protection and improvement efforts (FEPA, 1989). However, the country has the problem of implementation of laws and policies; hence the policy and law on solid waste management are poorly implemented in the country (Agunwamba, 1998).

Municipal solid waste collected in many cities of the developing countries are often disposed of in uncontrolled dumpsites and/or burnt in the open spaces and consequently causing significant pollution problems (surface and ground water contaminations) and the air. As primitive as open dump methods of solid wastes disposal are, it is observed that it remains the predominant means in developing countries. The open dump method of solid waste disposal is also considered dangerous because of the leaching effects of chemicals and biological contaminants in the wastes, which constitutes a direct risk to transmission of communicable diseases (Aderemi et al., 2011).

Groundwater is a very important source of water as it accounts for a percentage of the distributed water on earth which serves as major source of drinking in rural areas and urban centers in the world. Groundwater quality assessment is a measure of the condition of water relative to the requirements of one or more biotic species and/or to any human need or purposes. It involves the general measure and specific checks for constituents of groundwater and comparing it with recommended standards. Since water is an inevitable natural resource, it is important to check for the presence of contaminants and monitoring before usage to prevent the consumers from harm, research has shown that soil stratigraphy significantly influences contaminants in ground water (Abd El-Salam and Abu-Zuid, 2015; Md et al., 2014; Aderemi et al., 2011). This study was therefore designed to critically study the effects of the dumpsite on the groundwater being used for drinking and other domestic uses at Gbagede, Ilorin west local Government area of Kwara State as a case study.

\section{Materials and Methods Study Area}

The study was conducted at Gbagede located in Ilorin West Local Government Area in Kwara State, Nigeria located within Latitude $8^{\circ} 33^{\prime} 6^{\prime \prime}$ North and Longitude $4^{\circ} 44^{\prime} 43^{\prime \prime}$ East and Height above sea level is 367 meters. It has an area of $105 \mathrm{~km}^{2}$ and a population of 364,666 at the 2006 census, projected figure by 2016 was 490,111 . 


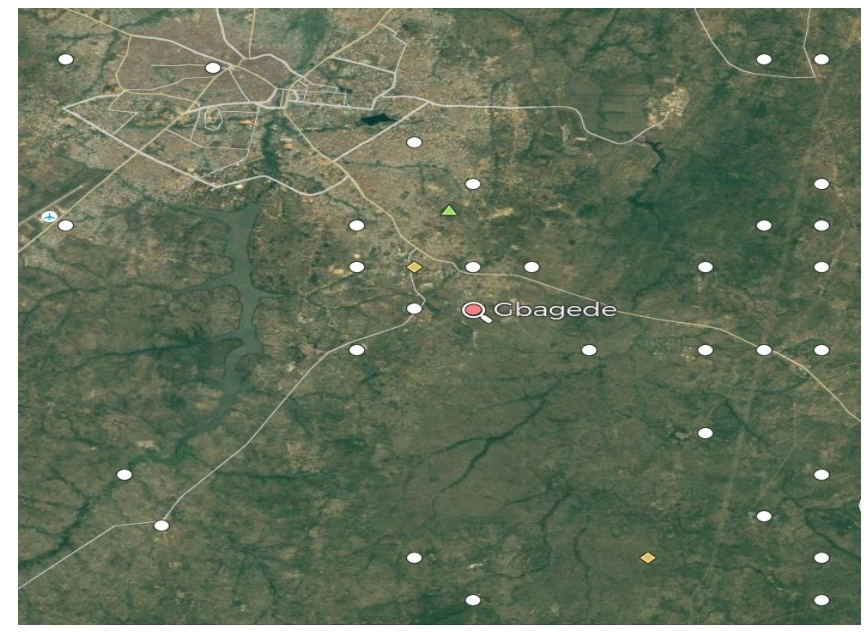

Fig1: Map showing Gbagede area

\section{Sampling Technique and Analysis}

A case study research method was adopted for three existing hand dug wells; GW1, GW2, GW3 located at 186 $\mathrm{m}, 290 \mathrm{~m}$ and $326 \mathrm{~m}$ respectively from the edge of the dumpsite were used as water sample points for groundwater quality tests. Water samples were collected in $150 \mathrm{cl}$ empty bottles that were earlier washed and cleaned with sterile water. Each sample was labelled according to the location, preserved at $4{ }^{\circ} \mathrm{C}$ and transported to the Chemistry Laboratory, University of Ilorin to determine the physicochemical parameters in each sample. Parameters evaluated include: $\mathrm{pH}$, total hardness, Total Dissolved Solids (TDS), Total Suspended Solids (TSS), alkalinity, turbidity, Chemical Oxygen Demand (COD), Biochemical Oxygen Demand (BOD), Dissolved Oxygen (DO), Nitrate ion, Chloride ion, Sulphate ion, Electrical conductivity, Calcium ion and Magnesium ion using standard laboratory procedures. Some of the parameters were recorded in-situ at the point of sampling while the analyses of other various water quality parameters were conducted

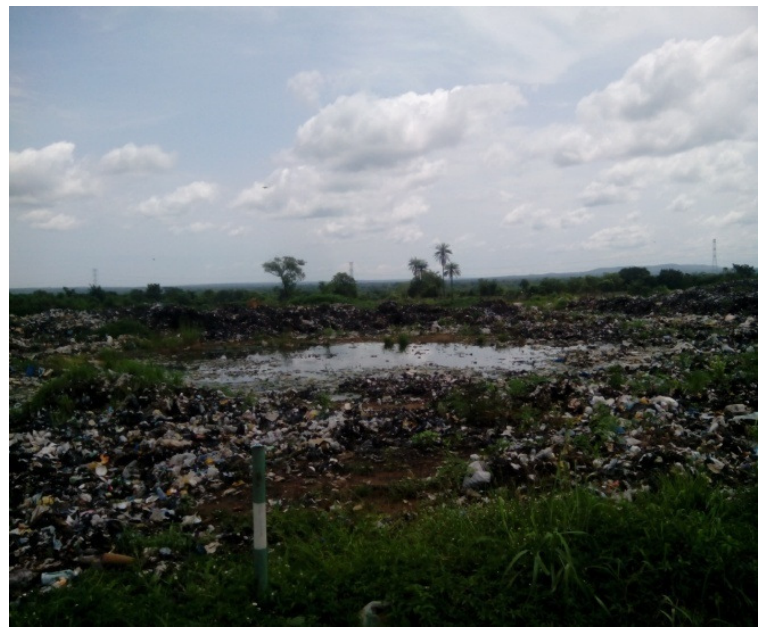

Fig.2: Gbagede dumpsite

following standard analytical methods as described by Kodarkar et al. (2008) and APHA (1998). Results of the laboratory analysis were subjected to data evaluation by standard statistical methods and the results were compared with International standards for drinking water and Nigerian Standards of Water Quality Guidelines as specified by WHO (2007) and Nigerian Industrial Standard (NIS) (2007) respectively.

Statistical analysis was also carried out on the laboratory result in accordance to Cohen (1988). The strength of correlation is determined by the magnitude of the Pearson correlation coefficient using the following general guidelines (Cohen, 1988):

a. $\quad 0.1<|r|<0.3=$ Correlation is of small strength

b. $0.3<|r|<0.5=$ Correlation is of medium strength

c. $|r|>0.5=$ Correlation is of strong strength

Where $|r|$ is the absolute Pearson correlation coefficient. 


\section{Results and Discussion}

The descriptive statistics analysis and summarized result of measured groundwater parameters are presented in Table 1. It was observed that minimum and maximum $\mathrm{pH}$ values were 6.55 and $6.60 \mathrm{mg} / \mathrm{L}$ respectively having $6.58 \pm 0.03$ as its mean value. The $\mathrm{pH}$ value indicates a slightly acidic condition and it is still within the stipulated water quality standards.

Similarly, parameters such as turbidity, conductivity, alkalinity, total hardness, TSS, DO, BOD, COD, $\mathrm{Ca}^{2+}$, $\mathrm{SO}_{4}{ }^{2-}, \mathrm{Cl}^{-}$and $\mathrm{NO}_{3}{ }^{2-}$ has their minimum and maximum values within NSDWQ and WHO standards with average value of $4.65 \pm 0.15,59.79 \pm 1.04,4.75 \pm 0.19$, $55.56 \pm 0.80, \quad 22.03 \pm 2.06, \quad 20.97 \pm 2.15$, $40.65 \pm 0.13, \quad 26.07 \pm 0.25, \quad 3.86 \pm 0.04$, $23.37 \pm 1.29, \quad 32.19 \pm 1.34, \quad 44.87 \pm 1.99$, $7.93 \pm 0.03,3.60 \pm 0.05$ respectively.

On the other hand, magnesium ion $\left(\mathrm{Mg}^{2+}\right)$ was observed to have minimum, maximum and mean value of 30.90 and 33.58 and $32.19 \pm 1.34 \mathrm{mg} / \mathrm{L}$ respectively. These values exceed the prescribed limit of $30 \mathrm{mg} / \mathrm{L}$ for drinking water purpose.

The significance of the observed correlation coefficients was tested using t-test as shown in Table 2. The correlation of two parameters revealed 86 positive correlation relationship out of 119 correlations. $\mathrm{pH}$ showed a negative correlation with all other parameters except alkalinity while Turbidity showed positive correlation except for alkalinity. Conductivity only had negative correlation with alkalinity and $\mathrm{Ca}^{2+}$ while negative correlation exists between alkalinity and other parameters except $\mathrm{Ca}^{2+}$. Positive correlation was observed between TS, TDS, DO, COD, $\mathrm{Ca}^{2+}$, and other parameters except their correlation with $\mathrm{Ca}^{2+}, \mathrm{Ca}^{2+}, \mathrm{Mg}^{2+}, \mathrm{Mg}^{2+}$ and $\mathrm{Mg}^{2+}$, $\left.\mathrm{SO}_{4}{ }^{2-}\right)$ respectively. Also, $\mathrm{TH}, \mathrm{TSS}$, $\mathrm{Mg}^{2+}, \mathrm{SO}_{4}{ }^{2-}, \mathrm{Cl}^{-}$and $\mathrm{NO}_{3}{ }^{2-}$ have positive correlation with all other parameters.

At $95 \%$ confidence level, only the correlation between BOD and $\mathrm{Ca}^{2+}$ was statistically found statistically significant because it has a value less than 0.05 as shown in Table 2.In addition to this, 96 out of the 119 correlations revealed strong strength correlation ( $\mathrm{r}$ value is greater than 0.5 ). This signifying high degree of differences in all the parameters considered at $95 \%$ confidence interval and also confirming presence of pollutants at irregular concentrations in all the water samples.

Perfect positive correlation existed between turbidity and nitrite, Conductivity and TDS, total hardness and TSS while it was perfect positive correlation between $\mathrm{pH}, \mathrm{TH}$ and TSS, alkalinity and total solids. 
Table 1: Characteristics of measured groundwater parameters

\begin{tabular}{|c|c|c|c|c|c|c|c|c|c|c|c|}
\hline \multirow{2}{*}{$\mathrm{S} / \mathrm{N}$} & \multirow{2}{*}{ Measure Parameters } & \multicolumn{3}{|c|}{ Samples } & \multicolumn{2}{|l|}{ Standards } & \multicolumn{5}{|c|}{ Descriptive Statistics } \\
\hline & & GW-1 & GW-2 & GW-3 & NSDWQ & WHO & Min. & Max. & Mean & Var. & Std. Dev. \\
\hline 1 & $\mathrm{pH}$ & 6.60 & 6.55 & 6.58 & $6.5-8.5$ & $6.5-8.5$ & 6.55 & 6.60 & 6.58 & 0.00 & 0.03 \\
\hline 2 & Turbidity (NTU) & 4.50 & 4.80 & 4.65 & NS & $1.0-5.0$ & 4.50 & 4.80 & 4.65 & 0.02 & 0.15 \\
\hline 3 & Conductivity $(\mu \mathrm{S} / \mathrm{cm})$ & 58.60 & 60.30 & 60.48 & 1000 & 600 & 58.60 & 60.48 & 59.79 & 1.08 & 1.04 \\
\hline 4 & Alkalinity $(\mathrm{mg} / \mathrm{L})$ & 4.96 & 4.60 & 4.70 & NS & 100 & 4.60 & 4.96 & 4.75 & 0.03 & 0.19 \\
\hline 5 & $\mathrm{TS}(\mathrm{mg} / \mathrm{L})$ & 38.60 & 46.22 & 44.20 & NS & NS & 38.60 & 46.22 & 43.01 & 15.58 & 3.95 \\
\hline 6 & $\mathrm{TH}(\mathrm{mg} / \mathrm{L})$ & 54.80 & 56.40 & 55.48 & 150 & 300 & 54.80 & 56.40 & 55.56 & 0.64 & 0.80 \\
\hline 7 & TSS (mg/L) & 20.10 & 24.20 & 21.80 & NS & 500 & 20.10 & 24.20 & 22.03 & 4.24 & 2.06 \\
\hline 8 & TDS (mg/L) & 18.50 & 22.02 & 22.40 & 500 & 500 & 18.50 & 22.40 & 20.97 & 4.62 & 2.15 \\
\hline 9 & $\mathrm{DO}(\mathrm{mg} / \mathrm{L})$ & 40.60 & 40.80 & 40.55 & NS & 5 & 40.55 & 40.80 & 40.65 & 0.02 & 0.13 \\
\hline 10 & BOD (mg/L) & 25.80 & 26.30 & 26.10 & NS & 5 & 25.80 & 26.30 & 26.07 & 0.06 & 0.25 \\
\hline 11 & $\mathrm{COD}(\mathrm{mg} / \mathrm{L})$ & 3.85 & 3.90 & 3.82 & NS & 10 & 3.82 & 3.90 & 3.86 & 0.00 & 0.04 \\
\hline 12 & $\mathrm{Ca}^{2+}(\mathrm{mg} / \mathrm{L})$ & 23.90 & 24.30 & 21.90 & 75 & 75 & 21.90 & 24.30 & 23.37 & 1.65 & 1.29 \\
\hline 13 & $\mathrm{Mg}^{2+}(\mathrm{mg} / \mathrm{L})$ & 30.90 & 32.10 & 33.58 & 0.20 & 30 & 30.90 & 33.58 & 32.19 & 1.80 & 1.34 \\
\hline 14 & $\mathrm{SO}_{4}{ }^{2-}(\mathrm{mg} / \mathrm{L})$ & 42.60 & 46.30 & 45.70 & 100 & 200 & 42.60 & 46.30 & 44.87 & 3.94 & 1.99 \\
\hline 15 & $\mathrm{Cl}^{-}(\mathrm{mg} / \mathrm{L})$ & 7.90 & 7.96 & 7.92 & 250 & 250 & 7.90 & 7.96 & 7.93 & 0.00 & 0.03 \\
\hline 16 & $\mathrm{NO}_{3}{ }^{2-}(\mathrm{mg} / \mathrm{L})$ & 3.55 & 3.65 & 3.60 & 50 & 45 & 3.55 & 3.65 & 3.60 & 0.00 & 0.05 \\
\hline
\end{tabular}

NS: Not specified 
Table 2: Correlation coefficients of sampled red groundwater parameters

\begin{tabular}{|c|c|c|c|c|c|c|c|c|c|c|c|c|c|c|c|c|}
\hline & $\mathrm{pH}$ & Turb. & Condt. & Alk. & $\mathrm{TS}$ & $\mathrm{TH}$ & TSS & TDS & DO & BOD & COD & $\mathrm{Ca}^{2+}$ & $\mathrm{Mg}^{2+}$ & $\mathrm{SO}_{4}{ }^{2-}$ & $\mathrm{Cl}^{-}$ & $\mathrm{NO}_{3}{ }^{2-}$ \\
\hline $\mathrm{pH}$ & 1 & & & & & & & & & & & & & & & \\
\hline Turb. & -0.993 & 1 & & & & & & & & & & & & & & \\
\hline Condt. & -0.748 & 0.819 & 1 & & & & & & & & & & & & & \\
\hline Alk. & 0.934 & -0.969 & -0.936 & 1 & & & & & & & & & & & & \\
\hline TS (mg/L) & -0.929 & 0.965 & 0.941 & -1.000 & 1 & & & & & & & & & & & \\
\hline TH (mg/L) & -1.000 & 0.996 & 0.767 & -0.944 & 0.939 & 1 & & & & & & & & & & \\
\hline TSS (mg/L) & -1.000 & 0.995 & 0.759 & -0.940 & 0.935 & 1.000 & 1 & & & & & & & & & \\
\hline TDS (mg/L) & -0.747 & 0.818 & 1.000 & -0.936 & 0.940 & 0.766 & 0.758 & 1 & & & & & & & & \\
\hline DO (mg/L) & -0.826 & 0.756 & 0.244 & -0.569 & 0.558 & 0.810 & 0.817 & 0.243 & 1 & & & & & & & \\
\hline BOD (mg/L) & -0.974 & 0.993 & 0.880 & -0.991 & 0.989 & 0.980 & 0.977 & 0.879 & 0.676 & 1 & & & & & & \\
\hline COD (mg/L) & -0.705 & 0.619 & 0.056 & -0.404 & 0.391 & 0.684 & 0.693 & 0.055 & 0.982 & 0.524 & 1 & & & & & \\
\hline $\mathrm{Ca}^{2+}(\mathrm{mg} / \mathrm{L})$ & -0.268 & 0.156 & -0.439 & 0.095 & -0.108 & 0.240 & 0.252 & -0.440 & 0.764 & 0.041 & 0.872 & 1 & & & & \\
\hline $\mathrm{Mg}^{2+}(\mathrm{mg} / \mathrm{L})$ & -0.341 & 0.447 & 0.879 & -0.655 & 0.666 & 0.368 & 0.357 & 0.880 & -0.248 & 0.547 & -0.426 & -0.814 & 1 & & & \\
\hline $\mathrm{SO}_{4}{ }^{2-}(\mathrm{mg} / \mathrm{L})$ & -0.884 & 0.932 & 0.972 & -0.993 & 0.994 & 0.897 & 0.891 & 0.971 & 0.466 & 0.967 & 0.291 & -0.214 & 0.741 & 1 & & \\
\hline $\mathrm{Cl}^{-}(\mathrm{mg} / \mathrm{L})$ & -0.997 & 0.982 & 0.696 & -0.904 & 0.898 & 0.995 & 0.996 & 0.695 & 0.866 & 0.954 & 0.756 & 0.339 & 0.270 & 0.846 & 1 & \\
\hline $\mathrm{NO}_{3}{ }^{2-}(\mathrm{mg} / \mathrm{L})$ & -0.993 & 1.000 & 0.819 & -0.969 & 0.965 & 0.996 & 0.995 & 0.818 & 0.756 & 0.993 & 0.619 & 0.156 & 0.447 & 0.932 & 0.982 & 1 \\
\hline
\end{tabular}

Correlation is significant at 0.05 level (2-tailed) 


\section{Conclusion and Recommendation}

Drinking water sources are under increasing threat from contamination; deteriorating water quality threatens the global gains made in improving access to drinking water. The physicochemical characteristics results showed no significant deviation from WHO and NSDWQ standard; it was however observed that the ground water quality improves with distance from the dumpsite implying a future threat of contaminants to the groundwater that serves as drinking and other domestic purposes to the inhabitants of Gbagede this calls for constant monitoring of the groundwater quality.

\section{References}

Abd El-Salam, M.M. and Abu-Zuid, G.I. (2015). Impact of landfill leachate on the groundwater quality: A case study in Egypt. Journal of Advanced Research, 6(4): 579-586.

Adekunle, M.I., Adetunji, A.M. Gbadebo A.M. and Banjoko, O.B. (2007). Assessment of Groundwater Quality in a Typical Rural Settlement in Southwest Nigeria. Int. J. Environ. Res. Public Health, 4(4): 307-318.

Agunwamba, J.C. (1998). Solid Waste Management in Nigeria: Problems and Issues. Environmental Management Journal, 22(6): 849856.

Akinbile, C.O. and Yusoff, M.S. (2011). Environmental Impact of Leachate Pollution on Groundwater Supplies in Akure, Nigeria. International Journal of Environmental Science and Development, 2(1): 81-86.

APHA (1998). Standard method for examination of Water and wastewater, American Public Health Association, 20 ${ }^{\text {th }}$ Edition, New York

Ayanshola, A.M. (2013). Evaluation of supply reliability and sustainability of household water use in Ilorin, Kwara State, Nigeria, Ph.D. Thesis, Department of Civil Engineering, University of Ilorin, Ilorin, Nigeria.

Burmamu, B.R., Law, P.L., Aliyu, H.H., and Ibrahim, Y.T. (2014). Environmental impacts and management strategies of solid waste disposal in Jimeta-Yola, Nigeria. International Journal of Environmental Engineering Science and Technology Research, 2(3):3-7.

Cosgrove, W.J. and Rijsberman, F.R. (2000). Making water everybody's business, World water Vision, World Water Council, Earthscan Publications Ltd, London, 27pp.

David, O.M. and Oluyege, A.O. (2014). Effect of Open Refuse Dumpsite on the Quality of Underground Water used for Domestic Purposes in AdoEkiti, Nigeria - A Public Health Awareness Study. Journal of Environment and Ecology. 5(2): 19.

Kodarkar, M.S., Diwan, A.D., Muruga, N., Kulkarni, K.M. and Anuradha, R. (2008). Methodology for water analysis, Indian association of aquatic Biologist, IAAB. Publication. No. 2

Kwabena, A.A. and Worlanyo, B.N. (2015). Analysis of Improper Disposal of Solid Wastes in a LowIncome Area of Accra, Ghana. Applied Economics and Finance, 2(1): 66-67.

Lo-Karija, M.K., Shihua, Q.I. and Ziggahs, Y.Y. (2013). Correlation 
among municipal solid waste pollution, fecal coli form water pollution and water borne diseases in juba/south Sudan. British Journal of Applied Science \& Technology 3(4): 1120-1143.

Md. Lokman Hossain, Satyajit Roy Das and Mohammed Kamal Hossain, (2014). Impact of Landfill Leachate on Surface and Ground Water Quality. Journal of Environmental Science and Technology, 7: 337346.

Musa, J.J. and Fumen, G.A. (2013). Assessment of portable water supply source in Ilorin Metropolis, Kwara State, Nigeria, International Journal of Agricultural Research Innovation and Technology, 3(1): 14 (http://www.ijarit.webs.com)

NIS (2007). Nigerian Standard for Drinking Water Quality, Standard Organization of Nigeria (SON), Abuja, Nigeria, SIS 554.

Okonkwo, J.O. (2010). Sanitation, portable water supply and environmental protection: benefits, progress and issues for sustainability in developing countries, AISA POLICY brief, No. 23

Raman, N. and Narayanan, D.S. (2008). Impact Of Solid Waste Effect On
Ground Water and Soil Quality Nearer to Pallavaram Solid Waste Landfill Site In Chennai. Rasayan Journal of Chemistry. 1(4): 828836.

Romijn, E. (2002). Groundwater quality and contamination, Groundwater contamination - a methodological guide, edited by Alexander Zaporozec, IHP-VI, Series on Groundwater No. 2, UNESCO, pp 17-22.

Ruiz-Mier, F. and Ginneken, M.V. (2006). Consumer cooperatives: an alternative institutional model for delivery of urban water supply and sanitation services? Water Supply and Sanitation Working Notes (www.ordbank.org/watsan)

Salam Abul, (2010) "Environmental and health impact of solid waste disposal at mangwaneni dumpsite in manzini: Swaziland", Journal of Sustainable Development in Africa, 12(7): 64-78.

WHO (2007). International standards for drinking water, World Health Organization, Geneva

Zaporozec, A. (1981). Ground-water pollution and its sources, Geojournal, 5(5): 457-471. 